\title{
Trypanocidal activity of Piper arboreum and Piper tuberculatum (Piperaceae)
}

\section{Luis Octávio Regasini, ${ }^{* 1}$ Fernando Cotinguiba, ${ }^{1}$ Gabriela Duó Passerini, ${ }^{2}$ Vanderlan da Silva Bolzani, ${ }^{1}$ Regina Maria Barretto Cicarelli, ${ }^{2}$ Massuo Jorge Kato, ${ }^{3}$ Maysa Furlan ${ }^{1}$}

\author{
${ }^{1}$ Departamento de Química Orgânica, Instituto de Química, Universidade Estadual Paulista "Júlio de Mesquita \\ Filho”, Rua Prof. Francisco Degni, SN, 14800-900, Araraquara-SP, Brazil, \\ ${ }^{2}$ Departamento de Ciências Biológicas, Faculdade de Ciências Farmacêuticas, Universidade Estadual Paulista \\ "Júlio de Mesquita Filho", Rodovia Araraquara-Jaú, Km 01, 14801-902 Araraquara-SP, Brazil, \\ ${ }^{3}$ Departamento de Química Fundamental, Instituto de Química, Universidade de São Paulo, Avenida Prof. Lineu \\ Prestes, 748, 05508-000 São Paulo-SP, Brazil
}

\begin{abstract}
RESUMO: “Atividade tripanocida de Piper arboreum e Piper tuberculatum (Piperaceae)" No escopo de nossas pesquisas sobre agentes bioativos da flora brasileira, vinte e quatro extratos e frações de Piper arboreum Aub. e Piper tuberculatum Jacq. (Piperaceae) tiveram sua atividade tripanocida avaliada através do ensaio colorimétrico com MTT. As atividades mais potentes foram manifestadas pelas frações hexânicas das folhas de $P$. arboreum $\left(\mathrm{CI}_{50}=13,3 \mu \mathrm{g} / \mathrm{mL}\right)$ e $P$. tuberculatum $\left(\mathrm{CI}_{50}=17,2 \mu \mathrm{g} / \mathrm{mL}\right)$. As frações hexânicas dos frutos de $P$. tuberculatum e $P$. arboreum também apresentaram efeito tóxico potente contra as formas epimastigotas de Trypanosoma cruzi, com valores de $\mathrm{CI}_{50}(\mu \mathrm{g} / \mathrm{mL})$ de 32,2 e 31,3, respectivamente. Adicionalmente, o estudo fitoquímico da fração hexânica das folhas de $P$. arboreum forneceu duas amidas pirrolidínicas, piperilina (1) e 4,5-diidropiperilina (2), que podem ser responsáveis pela atividade antiprotozoária desta fração.
\end{abstract}

Unitermos: Antiprotozoário, tripanocida, Piper arboreum, Piper tuberculatum, Piperaceae, Trypanosoma cruzi.

\begin{abstract}
In the scope of our ongoing research on bioactive agents from Brazilian flora, twenty-four extracts and fractions obtained from Piper arboreum Aub. and Piper tuberculatum Jacq. (Piperaceae) were screened for trypanocidal activity by using MTT colorimetric assay. The strongest activity was found in hexane fractions from the leaves of $P$. arboreum $\left(\mathrm{IC}_{50}=13.3 \mu \mathrm{g} /\right.$ $\mathrm{mL}$ ) and $P$. tuberculatum $\left(\mathrm{IC}_{50}=17.2 \mu \mathrm{g} / \mathrm{mL}\right.$ ). Hexane fractions of the fruits of $P$. tuberculatum and $P$. arboreum showed potent toxic effects on epimastigote forms of Trypanosoma cruzi, with values of $\mathrm{IC}_{50}(\mu \mathrm{g} / \mathrm{mL})$ of 32.2 and 31.3, respectively. Additionally, the phytochemical study of the hexane fraction of $P$. arboreum leaves furnished two pyrrolidine amides, piperyline (1) and 4,5-dihydropiperyline (2), which could be responsible, at least in part for the observed antiprotozoal activity.
\end{abstract}

Keywords: Antiprotozoal, trypanocidal, Piper arboreum, Piper tuberculatum, Piperaceae, Trypanosoma cruzi.

\section{INTRODUCTION}

Piperaceae species have been extensively investigated as a source of secondary metabolites with anti-Trypanosoma cruzi, antileishmanial, anxiolytic, anticonvulsant and anti-inflammatory activities (BarbosaFilho et al., 2006; Nakamura et al., 2006; Amorim et al., 2007; Saúde-Guimarães \& Faria, 2007; Quintans-Júnior et al., 2008). Phytochemical investigations of Piper species have led to the identification of typical classes of compounds such as amides, terpenes, benzoic acid derivatives, carotenes, and hydroquinones in addition to lignans, neolignans and a few alkaloids (Navickiene et al., 2000; Silva et al., 2002; Lago et al., 2004; Navickiene et al., 2006; Potzernheim et al., 2006; Barbosa-Filho et al., 2008; Regasini et al., 2008; Continguiba et al., 2009).

As part of our research aiming to uncover new trypanocidal compounds in Brazilian Piperaceae species, we have previously reported the occurrence of chromenes in P. aduncum and P. gaudichaudianum (Batista-Júnior et al., 2008). Additionally, hydroquinones and flavanones from leaves of $P$. crassinervium have been described as well (Lopes et al., 2008). In this context, we have screened various plants of Piper genus collected in the State of São Paulo (Brazil), P. arboreum Aub. and $P$. tuberculatum Jacq. (Piperaceae) were chosen 
<smiles>O=C(/C=C/C=C/c1ccc2c(c1)OCO2)N1CCCC1</smiles><smiles>CC1C[Sb](=O)([O-])CCN1/N=C/c1ccc([N+](=O)[O-])o1</smiles><smiles>O=C(/C=C/CCc1ccc2c(c1)OCO2)N1CCCC1</smiles>

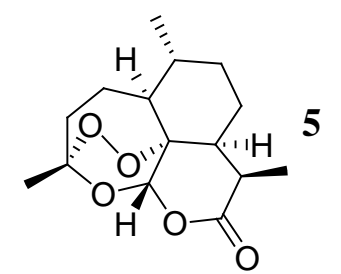<smiles>O=C(Cn1ccnc1[N+](=O)[O-])NCc1ccccc1</smiles><smiles>O=C(/C=C/C=C/c1ccc2c(c1)OCO2)N1CCCCC1</smiles>

Figure 1. Molecular structures of piperyline (1), 4,5-dihydropiperyline (2), benznidazole (3), nifurtimox (4), artemisinin (5), piperine (6). Pyrrolidine alkylamides 1 and $\mathbf{2}$ were isolated from Piper arboreum leaves.

for biological and chemical investigation, and to our knowledge there are no previous reports on antiprotozoal activity of these species.

In some Northeastern Brazil communities, $P$. tuberculatum, popularly known as "pimenta-d'arta" and "pimenta-longa" has been used as antidote for snake bite and sedative (Felipe et al., 2007). On the other hand, a decoction of $P$. arboreum (vernacular names: "fruto-demorcego", "alecrim-de-angola”, "pau-de-angola”, and "beto-preto") has been used against venereal diseases and infections of the urinary throat (Agra et al., 2007, 2008).

Thus, the major aim of the current study was to evaluate the extracts and fractions of leaves, stems, fruits and compounds from $P$. arboreum and P. tuberculatum for an anti-trypanosomal effect against epimastigote forms of Trypanosoma cruzi.

\section{MATERIAL AND METHODS}

\section{Plant material}

Specimens of $P$. arboreum and $P$. tuberculatum were cultivated from seeds under greenhouse conditions at the Institute of Chemistry, Universidade Estadual Paulista, Araraquara-SP, Brazil. Plant material was collected in May, 2006, and identified by Dr. Guillermo E. D. Paredes (Universidad Pedro Ruiz Gallo, Lambayeque, Peru). The vouchers specimens Kato-163 and Cordeiro-1936 were deposited at the herbarium of the Institute of Biosciences, Universidade de São Paulo, São Paulo-SP, Brazil.

\section{Extraction}

Shade-dried and powdered plant material (leaves, fruits or stems) of $P$. arboreum and P.tuberculatum (30.0 g) were extracted with ethanol (5 x $350 \mathrm{~mL})$, for three weeks at room temperature. After filtering, the solvent was evaporated under reduced pressure to yield a thick syrup, which was dispersed in methanol:water $(4: 1)$ and then successively partitioned with hexane and ethyl acetate. Samples of the ethanol extracts and the hexane, ethyl acetate, and lyophilized hydromethanol fractions were tested for potential trypanocidal activity.

\section{Isolation and identification of amides 1 and 2}

Thehexane fraction of theleaves of $P$. arboreum (880 mg) was subjected to column chromatography with silica gel (18 x $3.3 \mathrm{~cm}$ i.d.) and eluted with hexane:ethyl acetate (4:1). Twenty-five fractions $(10 \mathrm{~mL})$ were collected and checked by TLC on silica gel $\mathrm{F}_{254}$ plates developed with hexane:ethyl acetate (6:4), and revealed with Dragendorff reagent. Fractions 10-13 (520 mg) were purified by preparative TLC [hexane:dichlorometh ane:acetone:acetic acid $(6: 3: 1: 0.1)$, four elution] to yield piperyline (1; $310 \mathrm{mg}$ ) and 4,5-dihydropiperyline (2; 135 $\mathrm{mg}$ ). The molecular structures of these compounds were identified by comparison with literature data, mainly ${ }^{1} \mathrm{H}$ and ${ }^{13} \mathrm{C}$ NMR $\delta$ values (Alecio et al., 1998; Navickiene et al., 2000).

\section{Trypanocidal activity in vitro}

All experiments were performed with the Y-strain epimastigote forms of T. cruzi. They were grown axenically at $28{ }^{\circ} \mathrm{C}$ in liver-infusion Tryptose (LIT) medium supplemented with $10 \%$ fetal calf serum and harvested during the exponential phase of growth (7 dayold culture forms). Extracts, fractions and compounds were dissolved in DMSO and further added to a 96-well tissue culture plate (TPP) in different final concentrations. T. cruzi ( $1 \times 10^{7}$ parasites $/ \mathrm{mL}$ ) were added into each well and the same quantity of LIT medium was added into the controls wells. These plates were maintained at $28{ }^{\circ} \mathrm{C}$ for $72 \mathrm{~h} 10 \mu \mathrm{L}$ of a $2.5 \mathrm{mg} / \mathrm{mL}$ MTT-PMS solution was added to each well and the plates were incubated for 75 min in the dark at $28{ }^{\circ} \mathrm{C}$. A solution of $10 \%(100 \mu \mathrm{L})$ of sodium dodecyl sulfate (SDS) was added to the anterior solution and maintained at room temperature and in the 
dark at $30 \mathrm{~min}$. The absorbance of the samples had read at $595 \mathrm{~nm}$. The $50 \%$ inhibitory concentration $\left(\mathrm{IC}_{50}\right.$ ) values were determined by linear regression analysis after a $72 \mathrm{~h}$ incubation period. The $\mathrm{IC}_{50}$ values of samples and benznidazole (positive control) were determined. For the statistical analysis, probit's method was employed (Muelas-Serrano et al., 2000).

\section{RESULTS AND DISCUSSION}

Chagas' disease or American trypanosomiasis, caused by the protozoan flagellate $T$. cruzi, is an important public health problem in Latin America, affecting millions peoples annually (Sanchez-Burgos et al., 2003). The most common treatment for this disease involves two drugs, benznidazole (3) and nifurtimox (4) (Figure 1), which are active only during the acute and short-term chronic phases. Beznidazole (Rochagan ${ }^{\circledR /}$ Brazil and Radanil ${ }^{\circledR} /$ Argentina) is now the only drug still available since the production of nifurtimox was stopped. Besides presenting severe side effects, narrow therapeutic windows, and variable drug susceptibilities among $T$. cruzi strains result in low clinical efficacies for these 2-nitroimidazole (Coura \& Castro, 2002). For this reason, there is thus a distinct need for new, safer and more effective trypanocidal drugs.

Natural products have long been used as templates for the development of new lead compounds, which may be useful against parasitic diseases, such as artemisinin (5) (Figure 1), an antimalarial sesquiterpene isolated from Artemisia annua, popularly known as "quinhaosu" (Renslo \& McKerrow, 2006). In this context, several secondary metabolites of different structural patterns have proven active against $T$. cruzi (Saúde-Guimarães \& Faria, 2007), and screening of plant extracts is a valid strategy being exploited to discover trypanocidal agents (Leite et al., 2001; Takahashi et al., 2002; Luize et al., 2006; Pizzolatti et al., 2008).

In the present work, the ethanol extract and three fractions (hexane, ethyl acetate and hydromethanol) of the fruits, leaves and stems of $P$. arboreum and $P$. tuberculatum were evaluated for trypanocidal activity and the results are shown in Table 1.

Table 1. Toxic effects of Piper arboreum and Piper tuberculatum on epimastigote forms of Trypanosoma cruzi expressed by $\mathrm{IC}_{50}$ $\left(\mu \mathrm{g} \cdot \mathrm{mL}^{-1}\right)$.

\begin{tabular}{|c|c|c|c|}
\hline Plant part or compounds & $\begin{array}{c}\text { Extract or } \\
\text { fractions tested }\end{array}$ & $\begin{array}{c}\text { Piper } \\
\text { arboreum }\end{array}$ & $\begin{array}{c}\text { Piper } \\
\text { tuberculatum }\end{array}$ \\
\hline \multicolumn{4}{|l|}{ Fruits } \\
\hline & ethanol & 79.3 & 82.0 \\
\hline & hexane & 31.3 & 32.2 \\
\hline & ethyl acetate & 94.7 & 65.5 \\
\hline & hydromethanol & $>100$ & $>100$ \\
\hline \multicolumn{4}{|l|}{ Leaves } \\
\hline & ethanol & 66.1 & 44.6 \\
\hline & hexane & 13.3 & 17.2 \\
\hline & ethyl acetate & 47.6 & 49.0 \\
\hline & hydromethanol & $>100$ & $>100$ \\
\hline \multicolumn{4}{|l|}{ Stems } \\
\hline & ethanol & $>100$ & $>100$ \\
\hline & hexane & $>100$ & 79.3 \\
\hline & ethyl acetate & $>100$ & $>100$ \\
\hline & hydromethanol & $>100$ & $>100$ \\
\hline Piperyline (1) & - & $3.57(6.57 \mu \mathrm{M})$ & - \\
\hline 4,5-Dihydropiperyline (2) & - & $57.3(210 \mu \mathrm{M})$ & - \\
\hline \multirow[t]{2}{*}{ Benznidazole (3) } & - & $8.74(33.6 \mu \mathrm{M})$ & - \\
\hline & & & $\begin{array}{l}\text { Rev. Bras. Farmacogn. } \\
\text { Braz J. Pharmacogn. } \\
\text { 19(1B): Jan./Mar. } 2009\end{array}$ \\
\hline
\end{tabular}


In general, ethanol extracts (crude extracts) obtained from leaves and fruits exhibited stronger anti-trypanosomal activity than did those from stems. Hexane fractions were more effective than ethyl acetate and hydromethanol fractions, suggesting that the potential antichagasic compounds were in the lowpolarity fractions. The hexane fractions of the leaves of $P$. arboreum and $P$. tuberculatum exhibited the best activities against epimastigote form of $T$. cruzi, with values of $\mathrm{IC}_{50}(\mu \mathrm{g} / \mathrm{mL})$ of 13.3 and $17.2 \mu \mathrm{g} / \mathrm{mL}$, respectively, and most hexane fractions of the fruits showed an activity considered potent $\left(\mathrm{IC}_{50}<33 \mu \mathrm{g} / \mathrm{mL}\right.$ ). Ethyl acetate fractions of the leaves of $P$. tuberculatum and $P$. arboreum showed moderate trypanocidal activity, with values of $\mathrm{IC}_{50}(\mu \mathrm{g} / \mathrm{mL})$ of 49.0 and 47.6 , respectively. Hydromethanol fractions proved to be inactive, since the concentration at which these samples showed activity was over $100 \mu \mathrm{g} / \mathrm{mL}$.

Additionally, phytochemical fractionation of $P$. arboreum leaves furnished two amides responsible for the observed anti-trypanosomal effect of hexane fraction. Piperyline (amide 1) showed higher activity which an $\mathrm{IC}_{50}$ of $6.57 \mu \mathrm{M}$, almost five times more potent than positive control, benznidazole $\left(\mathrm{IC}_{50}=33.6 \mu \mathrm{M}\right)$. The hydrogenated analogue of piperyline (amide 2 ) was also assayed, exhibiting an $\mathrm{IC}_{50}$ of $210 \mu \mathrm{M}$. These data suggest that reduction of the double bond at positions 4 and 5 interferes with the anti-Trypanosoma cruzi activity.

Compounds $\mathbf{1}$ and $\mathbf{2}$ are pyrrolidine alkylamides of remarkable occurrence in Piper species whose biological properties have been extensively demonstrated in the literature (Alecio et al., 1998; Koul et al., 2000; Wei et al., 2004; Venkatasami et al., 2004). Other amides from Piper species are among the natural products of interest since many of it compounds display a broad range of antiprotozoal activities (Raay et al., 1999; Bodiwala et al., 2007; Freire-de-Lima et al., 2008). Kapil (1993) reported an investigation of piperine (amide 6) activity against promastigote forms of Leishmania donovani. More recently, Ribeiro et al. (2004) reported the highly significant trypanocidal activity of piperine and its synthetic derivatives on epimastigotes and amastigotes of $T$. cruzi.

\section{CONCLUSION}

It may be concluded from the study that $P$. arboreum and $P$. tuberculatum have potential anti-trypanosomal activity based on toxic effect against epimastigote form of $T$. cruzi. Furthermore, hexane fractions of the leaves of $P$. arboreum and $P$. tuberculatum could be an important source of promising antiprotozoal compounds, useful for developing of novel anti-Trypanosoma cruzi agents. Two pyrrolidine alkylamides, piperyline (1) and 4,5-dihydropiperyline (2), have been isolated from $P$. arboreum leaves, which could be responsible, at least in part for the observed trypanocidal effect. In view of these findings, further chemical and pharmacological investigations to identify others secondary metabolites and to evaluate the potential of these Piper species as antichagasic agents in vivo are recommended.

\section{ACKNOWLEDGEMENTS}

The authors wish to thank the Fundação de Amparo à Pesquisa do Estado de São Paulo (FAPESP), Programa BIOTA-FAPESP (The Biodiversity Virtual Institute) and, Coordenação de Aperfeiçoamento de Pessoal de Nível Superior (CAPES), for financial support.

\section{REFERENCES}

Agra MF, Freitas PF, Barbosa-Filho JM 2007. Synopsis of the plants as medicinal and poisonous in Northeast of Brazil. Rev Bras Farmacogn 17: 114-140.

Agra MF, Silva KN, Basílio IJLD, França PF, Barbosa-Filho JM 2008. Survey of medicinal plants used in the region Northeast of Brazil. Rev Bras Farmacogn 18: 472-508.

Alécio AC, Bolzani VS, Young MCM, Kato MJ, Furlan M 1998. Antifungal amide from leaves of Piper hispidum. $J$ Nat Prod 61: 637-639.

Amorim MFD, Diniz MFFM, Araújo MST, Pita JCLR, Dantas JG, Ramalho JA, Xavier AL, Palomaro TV, Júnior NLB 2007. The controvertible role of kava (Piper methysticum G. Foster), an anxiolytic herb, on toxic hepatitis. Rev Bras Farmacogn 17: 448-454.

Barbosa-Filho JM, Piuvezam MR, Moura MD, Silva MS, Lima KVB, Cunha EVL, Fechine IM, Takemura OS 2006. Anti-inflammatory activity of alkaloids: A twentycentury review. Rev Bras Farmacogn 16: 109-139.

Barbosa-Filho JM, Alencar AA, Nunes XP, Tomaz ACA, Sena-Filho JG, Athayde-Filho PF, Silva MS, Souza MFV, da-Cunha EVL 2008. Sources of alpha-, beta, gamma-, delta- and epsilon-carotenes: A twentieth century review. Rev Bras Farmacogn 18: 135-154.

Batista-Júnior JM, Lopes AA, Ambrósio DL, Regasini LO, Kato MJ, Bolzani VS, Cicarelli RMB, Furlan M 2008. Natural chromenes and chromenes derivatives as potential anti-trypanosomal agents. Biol Pharm Bull 31: 538-540.

Bodiwala HS, Singh G, Singh R, Dey CS, Sharma SS, Bhutani KK, Singh IP 2007. Antileishmanial amides and lignans from Piper cubeba and Piper retrofractum. $J$ Nat Med 61: 418-421.

Cotinguiba F, Regasini LO, Bolzani VS, Debonsi HM, Passerini GD, Cicarelli RMB, Kato MJ, Furlan M 2009. Piperamides and their derivatives as potential antitrypanosomal agents. Med Chem Res (doi: 10.1007/ s00044-008-9161-9).

Coura JR, Castro SL 2002. A critical review on Chagas disease chemotherapy. Mem Inst Oswaldo Cruz 97: 3-24.

Felipe FCB, Sousa-Filho JT, Souza LEO, Silveira JA, Uchoa DEA, Silveira ER, Pessoa ODL, Viana GSB 2007. Piplartine, an amide alkaloid from Piper tuberculatum, 
presents anxiolytic and antidepressant effects in mice. Phytomedicine 14: 605-612.

Freire-de-Lima L, Ribeiro TS, Rocha GM, Brandão BA, Romeiro A, Mendonça-Previato L, Previato JO, Lima MED, Carvalho TMU, Heise N 2008. The toxic effects of piperine against Trypanosoma cruzi: ultrastructural alterations and reversible blockage of cytokinesis in epimastigote forms. Parasitol Res 102: 1059-1067.

Kapil A 1993. Piperine: a potent inhibitor of Leishmania donovani promastigotes in vitro. Planta Med 59: 474.

Koul S, Koul JL, Taneja SC, Dhar KL, Jamwal DS, Singh K, Reen RK, Singh J 2000. Structure-activity relationship of piperine and its synthetic analogues for their inhibitory potential of rat hepatic microsomal constitutive and inducible cytochrome $\mathrm{P} 450$ activities. Bioorg Med Chem 8: 251-258.

Lago JHG, Ramos CS, Casanova DCC, Morandim AA, Bergamo DCB, Cavalheiro AJ, Bolzani VS, Furlan M, Guimarães EF, Young, MCM, Kato MJ 2004. Benzoic acid derivatives from Piper species and their fungitoxic activity against Cladosporium cladosporioides and C. sphaerospermum. J Nat Prod 67: 1783-1788.

Leite JPV, Lombardi JA, Chiari E, Oliveira AB 2001. Isolamento biomonitorado de uma substância tripanossomicida de Arrabidaea triplinervia (Bignoniaceae), o ácido ursólico. Rev Bras Farmacogn 11: 77-87.

Lopes AA, López SN, Regasini LO, Batista-Júnior JM, Ambrósio DL, Kato MJ, Bolzani VS, Cicarelli RMB, Furlan M 2008. In vitro activity of isolated compounds from Piper crassinervium against Trypanosoma cruzi. Nat Prod Res 22: 1040-1046.

Luize PS, Ueda-Nakamura T, Dias-Filho BP, Cortez DAG, Nakamura CV 2006. Activity of neolignans isolated from Piper regnellii (MIQ.) C. DC. var. pallescens (C. DC.) Yunck against Trypanosoma cruzi. Biol Pharm Bull 29: 2126-2130.

Muelas-Serrano S, Nogal-Ruiz J, Gómez-Barrio A 2000. Setting of a colorimetric method to determine de viability of Trypanosoma cruzi epimastigotes. Parasitol Res 86: 999-1002.

Nakamura CV, Santos AO, Vendrametto MC, Luize OS, DiasFilho, BP, Cortez DAG, Ueda-Nakamura T 2006. Atividade antileishmania do extrato hidroalcoólico e de frações obtidas de folhas de Piper regnellii (Miq.) C. DC. var. pallescens (C. DC.) Yunck. Rev Bras Farmacogn 16: 61-66.

Navickiene HMD, Alécio AC, Kato MJ, Bolzani VS, Young MCM, Cavalheiro AJ, Furlan M 2000. Antifungal amides from Piper hispidum and Piper tuberculatum. Phytochemistry 55: 621-626.

Navickiene HMD, Morandim AA, Alécio AC, Regasini LO, Bergamo DC, Telascrea M, Cavalheiro AJ, Lopes MN, Bolzani, VS, Marques MO, Young MCM, Kato MJ 2006. Composition and antifungal activity of essential oil from Piper aduncum, Piper arboreum and Piper tuberculatum. Quim Nova 29: 467-470.

Pizzolatti MG, Mendes BG, Cunha-Júnior A, Soldi C, Koga AH, Eger I, Grisard EC Steindel M 2008. Trypanocidal activity of coumarins and styryl-2-pyrones from Polygala sabulosa A.W. Bennet (Polygalaceae). Rev Bras Farmacogn 18: 177-182.

Potzernheim MCL, Bizzo HR, Vieira RF 2006. Análise dos óleos essenciais de três espécies de Piper coletadas na região do Distrito Federal (Cerrado) e comparação com óleos de plantas procedentes da região de Paraty, RJ (Mata Atlântica). Rev Bras Farmacogn 16: 246251.

Quintans-Júnior LJ, Almeida JRGS, Lima JT, Nunes XP, Siqueira JS, Oliveira LEG, Almeida RN, AthaydeFilho PF, Barbosa-Filho JM 2008. Plants with anticonvulsant properties - a review. Rev Bras Farmacogn 18 (Supl.): 798-819.

Raay B, Medda S, Mukhopadhyay S, Basu MK 1999. Targeting of piperine intercalated in mannose-coated liposomes in experimental leishmaniasis. Indian $J$ Biochem Biophys 36: 248-251.

Regasini LO, Cotinguiba F, Siqueira JR, Bolzani VS, Silva DHS, Furlan M, Kato MJ 2008. Radical scavenging capacity of Piper arboreum and Piper tuberculatum (Piperaceae). Lat Am J. Pharm 27: 900-903.

Renslo AR, McKerrow JH 2006. Drug discovery and development for neglected parasitic diseases. Nat Chem Biol 2: 701-710.

Ribeiro TS, Freire-de-Lima L, Previato JO, Mendonça-Previato L, Heise N, Lima MEF 2004. Toxic effects of natural piperine and its derivatives on epimastigotes and amastigotes of Trypanosoma cruzi. Bioorg Med Chem Lett 14: 3555-3558.

Sanchez-Burgos G, Mezquita-Vega RG, Escobedo-Ortegon J, Ramirez-Sierra MJ, Arjona-Torres A, Ouaissi A, Rodrigues MM, Dumonteil E 2003. Comparative evaluation of therapeutic DNA vaccines against Trypanosoma cruzi in mice. FEMS Immunol Med Microbiol 50: 333-341.

Saúde-Guimarães DA, Faria AR 2007. Substâncias da natureza com atividade anti-Trypanosoma cruzi 2007. Rev Bras Farmacogn 17: 455-465.

Silva RV, Navickiene HMD, Kato MJ, Bolzani VS, Méda CI, Young MCM, Furlan M 2002. Antifungal amides from Piper arboreum and Piper tuberculatum. Phytochemistry 59: 521-527.

Takahashi JA, Vieira HS, Silva EA, Boaventura MAD, Oliveira AB, Chiari E 2002. Preparation and activity of diterpenoids against trypomastigotes of Trypanosoma cruzi. Rev Bras Farmacogn 12 (Supl): 118-120.

Venkatasamy R, Faas L, Young AR, Raman A, Hider RC 2004. Effects of piperine analogues on stimulation of melanocyte proliferation and melanocyte differentiation. Bioorg Med Chem 12: 1905-1920.

Wei K, Li W, Koike K, Pei Y, Chen Y, Nikaido T 2004. New amide alkaloids from the roots of Piper nigrum. J Nat Prod 67: 1005-1009. 